\title{
LXXIII. The theory of electrolytic dissociation. (A rectification of the "correction" by professor Harry C. Jones)
}

\section{Louis Kahlenberg Ph.D.}

To cite this article: Louis Kahlenberg Ph.D. (1905) LXXIII. The theory of electrolytic dissociation. (A rectification of the "correction" by professor Harry C. Jones), Philosophical Magazine Series 6, 10:60, 662-664, DOI: 10.1080/14786440509463415

To link to this article: http://dx.doi.org/10.1080/14786440509463415

册Published online: 16 Apr 2009.

Submit your article to this journal $[\pi$

Џll Article views: 3

Q View related articles $\longleftarrow$

Citing articles: 1 View citing articles $\square$ 


\section{$\left[\begin{array}{ll}662 & ]\end{array}\right.$}

LXXIII. The Theory of Electrolytic Dissociation. (A Rectification of the "Correction" by Professor Harry C. Jones.) By Louts Kahlenberg, Ph.D., Professor of Physical Chemistry in the University of Wisconsin *.

THE "Correction" by H. C. Jones $†$ which recently appeared in this Journal is founded upon an error on the part of its author to which I desire to call attention. The supposed "correction" relates to the following passage which Jones quotes from p. 215 of my paper $\ddagger$ :- "In 1901 I published a list of results of cryoscopic and ebullioscopic determinations made with typical aqueous solutions of electrolytes and non-electrolytes, and also a list of molecular conductivity determinations of the same electrolytes at $0^{\circ}$ and at $95^{\circ}$. It is unnecessary to discuss again the details of these results which are rather voluminous. Suffice it to state that a comparison of the freezing-point values with the molecular conductivity at $0^{\circ}$, and also of the boiling-point values with the molecular conductivity at $95^{\circ}$, revealed the fact that there is no such connexion between freezing-points and boilingpoints of solutions on the one hand, and their conductivity on the other, as is claimed by the theory of Arrhenius. In numerous cases not even a qualitative agreement exists. The facts presented in the paper cited have since been corroborated by Smits in his careful vapour-tension measurements, and by H. C. Jones and co-workers in their molecular weight determinations on solutions."

Now it is clear that this passage relates to aqueous solutions as the first sentence of it explicitly states, which fact has been entirely overlooked by Jones, for after quoting the above he continues $\S$ :- " Referring to the paper cited by L. Kahlenberg $\|$, and turning to page 342, we find the following:Under the heading "Behaviour of non-aqueous electrolytic solutions' the following supposed 'facts are presented.' 'Again, many solutions have been found in which the solute according to molecular weight determinations is undissociated, and which nevertheless possess excellent power of conducting electricity.'.... 'According to Dutoit and Friderich, $\mathrm{CdI}_{2}$, $\mathrm{LiCl}, \mathrm{NaI}, \mathrm{HgCl}_{2}$, and $\mathrm{NH}_{4} \mathrm{CnS}$ have normal molecular weights in acetone, and yet these solutions are conductors of electricity." "Jones then proceeds to give a general statement

\footnotetext{
* Communicated by the Author.

$\dagger$ Phil. Mag. [6] x. p. 157 (1905).

$\ddagger$ Phil. Mag. 6 ] ix. p. 214 (1905).

Loc, cit. p. 158 .

If Journ. Phys. Chem. v. p. 339 (1901).
} 
of the results of his molecular weight determinations of the salts just mentioned in acetone solutions. It is clear, therefore, that he has wrongly applied the passage which he quotes from p. 215 of my paper * to non-aqueous solutions, for it relates to aqueous solutions $t$, as has been pointed out above, and his "correction" is consequently not pertinent.

The passage quoted by Jones from p. 215 of my paper does refer to the molecular weight determinations on aqueous solutions made by him and his co-workers,-see the article by Jones and Getman, Amer. Chem. Journ. xxxi. p. 303 (1904)f. In this paper experimental data are presented showing the change of molecular lowering of the freezing-point and also the alteration of the molecular conductivity with change of the concentration of the solutions. A goodly number of the salts which were thus investigated are the same as those I had used, and an examination of the experimental results which Jones obtained with these salts shows that there is no such relation between molecular weight determinations on the one hand and conductivity measurements on the other as the theory of Arrhenius requires. Moreover, the behaviour of the salts which they studied in addition to those which $I$ measured, also substantiates this contention. The determinations of Jones and his co-workers therefore constitute, indeed, a corroboration of my work as was stated in this Journal $\S$.

I would like to emphasize here that in my articlen I have not referred to the interpretations which Jones himself puts upon his experimental data, or the mode of reasoning by which he arrives at his conclusions. A scrutiny of the method of "reasoning" adopted by Jones shows that when summed up it simply consists of assuming for any specific solution just so much polymerization and electrolytic dissociation of the dissolved molecules, together with combination of the latter with the solvent molecules, as may be necessay to make the results of the experimental measurements conform to the

* Phil. Mag. [6] ix. (1905).

+ Indeed, I do not consider the relations between molecular weight and conductivity in the case of non-aqueous solutions till seven pages later in my paper. See Phil. Mag. [6] ix. p. 222 (1905).

$\ddagger$ The earlier work by Jones and Chambers, and Chambers and Frazer, Amer. Chem. Journ. xxiii. p. 89 and p. 512 (1900), had previously been considered by me, Journ. Phys. Chem. v. p. 359 (1901).

$\S$ The measurements of Smits, which were mentioned in the same connexion, also confirm my experimental work, which that author has frankly admitted, Zeit. phys. Chem. xxxix. p. 385 (1902). Smits mentions the work of Jones, Chambers, and Frazer in the same connexion, l. $c$. bottom of p. 429 .

if Phil. Mag. [6] ix. p. 214 (1905). 
661 Mr. A. A. Robb on the Conduction of Electricity

requirements of the simple gas laws and the theory of electrolytic dissociation. Such cases as the acetone solutions of $\mathrm{CdI}_{2}, \mathrm{NH}_{4} \mathrm{CnS}$, and $\mathrm{NaI}$, for instance, which are good electrolytes though the ebullioscopic determinations yield molecular weights of $448 \cdot 6$ to $510 \cdot 7,88 \cdot 1$ to $101 \cdot 6$, and $133 \cdot 2$ to 143.0 for the respective salts, whereas the corresponding theoretical values are $336,76 \cdot 2$, and $149 \cdot 9 *$, are consequently readily "harmonized" with the theory of electrolytic dissociation by Jones, by assuming the required amount of polymerization and dissociation necessary for his purpose. It is quite unnecessary to dwell upon this further, for in a recent article, which should prove interesting reading to all who belong to what he calls the "dilute school," J.J. Van Laar $\uparrow$ has thoroughly exposed the fallacy of such a course of reasoning as that adopted by Jones and Getman.

Finally, as to whether the facts upon which I have based my arguments against the theory of electrolytic dissociation are real or merely "supposed," as Jones would have it, I shall gladly leave to the judgment of the reader.

Laboratory of Physical Chemistry,

University of Wisconsin, Madison. July 190 s.

LXXIV. On the Conduction of Electricity through Gases between Parallel Plates.-Part II. By ALFred A. RoBb †. THE writer has already shown $\S$ that the differential 1 equation

$$
\begin{aligned}
\frac{d^{2} \mathrm{X}^{2}}{d x^{2}}=8 \pi e\left(\frac{1}{\mathrm{R}_{1}}+\frac{1}{\mathrm{R}_{2}}\right) & \left\{q-\frac{\alpha}{e^{2} \mathrm{X}^{2}\left(\mathrm{R}_{1}+\mathrm{R}_{2}\right)^{2}}\right. \\
& \left.\times\left(i+\frac{\mathrm{R}_{2}}{8 \pi} \frac{d \mathrm{X}^{2}}{d x}\right)\left(i-\frac{\mathrm{R}_{1}}{8 \pi} \frac{d \mathrm{X}^{2}}{d x}\right)\right\}
\end{aligned}
$$

* The data are those of Jones, Amer. Chem. Journ. xxvii. p. 16 (1902). They are somewhat different from those of Dutoit and Friderich who simply state that the molecular weights are normal, without giving specitic figures, Bull. Soc. Chim. Paris, [3] xix. p. 334 (1898). Jones did not investigate $\mathrm{LiCl}$ in acetone on account of its slight solubility. The $\mathrm{HgCl}_{2}$ solution had but slight conductivity, and its molecular weight determination yielded the values 267.9 and $271 \cdot 2$ (but two determinations were made) as compared with $271 \cdot 2$, the theoretical. This latter caso then presents no difficulties for the dissociation theory, as Jones well states.

+ Chemisch Weekblad, ii. pp. 1.16 See also the abstract in Chem. Centralblatt, Ixxvi. p. 491 (1905).

I Communicated by the Authur.

§ Phil, Mag. August 1905. 